\title{
繰返しせん断に起因した粘土層の沈下に及ぼす周期の影響 EFFECTS OF LOADING PERIOD OF CYCLIC SHEAR ON
THE SETTLEMENT OF SATURATED CLAYEY LAYER
}

\author{
松田 博*.大原資生** \\ By Hiroshi MATSUDA and Sukeo ŌHARA
}

\begin{abstract}
Two-way strain controlled cyclic simple shear tests with different loading periods $(0.2-10$ s) are performed for normally and overconsolidated kaolinite clay specimens (OCR $=1,6)$. The specimens are subjected to cyclic shear under undrained condition and subsequently the cumulated excess pore water pressure are dissipated. In conclusion, it is clarified that for normally consolidated clay, the larger the period of cyclic shear, the larger the excess pore water pressure becomes and that with the increase of OCR, effects of the period on the cumulated excess pore water pressure disappear. As for the settlement, however, the effects of period can not be seen.

Keywords : period, dynamic, settlement, clay, pore pressure
\end{abstract}

\section{1.まえがき}

軟弱な粘土層が地震，波浪などに起因した繰返しせん 断を受けることは数多くみられ，そのために地盤が沈下

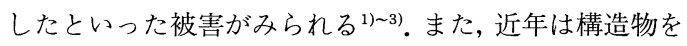
こうした軟弱地盤上に築造することが多くなってきてお ク, 構造物が精密化している現在, 粘土層に繰返しせん 断が作用した場合の挙動について明確にする必要があ る.

すでに報告しているように4)，軟弱な粘土層が繰返し せん断を受けると, 粘土層内では過剩間隙水圧が累積し, 特に地震時のように繰返しせん断の継続時間が短い場 合, 地震中においては, ほぼ非排水状態が保たれるため に, 過剰間隙水圧は残留する。しかし, 時間経過ととも にそれは消散し粘土層は沈下する。

粘土地盤が地震によって沈下したという例は, 実際日 本, メキシコにおいて確認されており，特に，1957 年の メキシコ地震においては, 地震直後に大きい沈下を生じ, 地震後の沈下速度が地震前に比べると著しく増加したと いう報告がなされている1).また, 1985 年のメキシコ地震 でも地震直後に構造物が $3.8 \mathrm{~cm}$ 沈下したという報告が ある2).

* 正会員 工博 山口大学助教授 工学部土木工学科 （厂755 宇部市常盤台）

** 正会員 工博 宇部工業高等専門学校校長 (同上)
このような繰返しせん断に起因した沈下は, 室内試験 によっても確認されている4). すなわち, カオリン粘土の 動的単純せん断試験により，そのような沈下は正規圧密 粘土だけでなく過圧密粘土でも生じ, その大きさは繰返 しせん断中に累積した過利間隙水圧の大きさ，粘土の過 圧密比等に依存することが示された.

一方，地震，波浪においては，地盤に作用する繰返し せん断の周期は異なり, 通常の地震においては卓越周期 が0.5〜2.0 秒程度であるのに対して, 波浪では $5 \sim 10$ 秒と長い. 従来行われた粘性土の動的強度に関する結 果 ${ }^{5) ~ 8)}$ によると, 周期を $0.1 \sim 100$ 秒の範用で変化させる と, 明らかに周期の影響がみられる。また繰返し載荷の 周期は過剰間隙水圧にも影響するという報告があ る ${ }^{9), 11)}$. しかし, 繰返しせん断の周期が過㮃間隙水圧の累 積過程およびその消散に伴う沈下に及ぼす影響について は明確にされていない点が多い.

そこで, ここでは動的単純せん断試験機を用いて，過 圧密比の異なる $(\mathrm{OCR}=1 \sim 6)$ 飽和粘土供試体に種々 の周期の繰返しせん断ひずみを非排水状態で与えた後, 累積した過㮃間陌水圧を消散させるという実験を行い, 繰返しせん断の周期が, 累積する過剩間陌水圧の大きさ およびその消散によって生じる粘土層の沈下に及ぼす影 響について調べた。 


\section{2. 繰返しせん断によって累積する過剩間隙 水圧およびその消散に伴う沈下について}

すでに飽和粘土に繰返しせん断ひずみが作用した場 合，累積する過剰間隙水圧の大きさは，せん断ひずみ振 幅と繰返し回数の関数として次式で与えられることを示 した4).

$$
u_{d y n} / \sigma_{v o}^{\prime}=n /(\alpha+\beta \cdot n)-\Psi \cdot
$$

ここに， $\alpha, \beta$ は次式で与えられる.

$$
\alpha=A \cdot\left(\gamma_{d y n}\right)^{m}
$$

$$
\beta=\gamma_{d y n} /\left(B+C \cdot \gamma_{d y n}\right)
$$

ただし, $\gamma_{d y n}>-B / C$

また， $A, B, C, m$ は定数である. 式(1)において, $\Psi$ は過圧密粘土の場合, 繰返しせん断の初期において生 じる負圧に対する補正值であって，ひずみ振幅との関係 で次式で表わされる。

$$
\Psi=D+E \cdot \log \gamma_{d y n}
$$

ここに $D, \mathrm{E}$ は定数である.

したがって式（1），（2），（3），（4）により，累積す る過剰間隙水圧はひずみ振幅と繰返し回数の関係として 表わされる.

繰返しせん断によって累積した過剩間隙水圧が消散す ると間隙比が減少する。過剩間隙水圧消散によって生じ る間隙比の変化は, $e \sim \log p$ 関係において過剰間隙水圧 消散時の勾配を $C_{d y n}$ とすると次式で与えられることが 示されている4).

$$
\Delta e=C_{d y n} \times \log \left\{1 /\left(1-u_{d y n} / \sigma_{v o}^{\prime}\right)\right\}
$$

これより, 繰返しせん断によって生じる沈下ひずみ $\varepsilon_{v}$ は

$$
\varepsilon_{v}=C_{d y n} /\left(1+e_{o}\right) \times \log \left\{1 /\left(1-u_{d y n} / \sigma_{v o}^{\prime}\right)\right\}
$$

となるここに， $e_{0}$ は供試体が繰返しせん断を受ける前 の間吵比である。また，式 $(5)$ ，（6）中の $u_{d y n} / \sigma_{v o}^{\prime}$ は式 （1）で与えられることから，繰返しせん断後に生じる沈 下ひずみも繰返し回数とUずみ振幅の関係として表わさ れる。

ここでは以上の関係を使って，過圧密比の異なる供試 体について, 繰返しせん断の周期が過剩間隙水圧の累積, およびその消散によって生じる沈下に及ぼす影響を調べ た.

\section{3．試料および供試体}

本実験で使用した試料は, 粉末状のカオリン粘土で, その粒径過積曲線を Fig. 1 に, 物理諸定数を Table 1 に 示す．供試体の作製方法は次のとおりである．この粉末 状の粘土に含水比が約 $80 \%$ になるように脱気水を加え よく攪挥した後, 約 24 時間放置する. そして, 真空室に おいて約 30 分間脱気した後, せん断箱のゴムスリーブの 中に詰める，このようにして詰められた試料を，所定の 圧密圧力 $\left(\sigma_{v o}^{\prime}=49 \mathrm{kPa}\right)$ で 22 時間圧密する. 圧密後の供 試体は, 直径 $75 \mathrm{~mm}$, 高さ約 $20 \mathrm{~mm}$ の円盤状であり，そ のときの間隙比は, $1.29 〜 1.33$ であった.

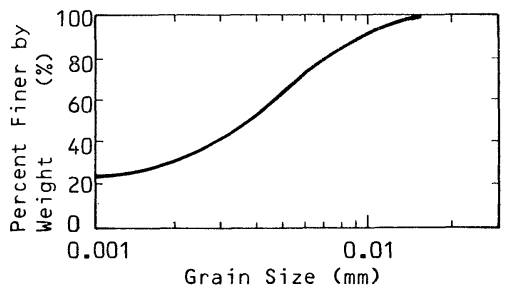

Fig. 1 Grain size distribution curve.

Table 1 Physical properties of sample.

\begin{tabular}{|ll|l|}
\hline Specific Gravity & $G_{S}$ & 2.718 \\
\hline Liquid Limit & $W_{L}$ & $53.5 \%$ \\
\hline Plastic Limit & $W_{P}$ & $28.5 \%$ \\
\hline Plasticity Index & $I_{P}$ & 25.0 \\
\hline Average Grain Size & $D_{50}$ & $3.8 \mu \mathrm{m}$ \\
\hline
\end{tabular}

\section{4. 実験装置および実験方法}

本実験で用いた実験装置は, 電気油圧サ一ボ式動的単 純せん断試験機4)である.

せん断箱は Kjellman 型と同型で，応力制御方式また はひずみ制御方式により，動的および静的せん断応力を 負荷することができるもので，本実験ではひずみ制御方 式を用いた。なお，実験装置の詳細については，すでに 報告している4)のでここでは省略する.

実験は，所定の圧密圧力 $\sigma_{v o}^{\prime}$ で予圧密して正規正密状 態および過圧密状態 $(\mathrm{OCR}=1 ， 6)$ にある供試体に，非 排水状態でひずみ振幅 $\gamma_{d y n}$ が一定の繰返しせん断を与 えた. $\gamma_{d y n}$ は $0.05 \%$ 3.00\%間で変化させ, 繰返し回数 $n$ は 200 回とした. そして,それぞれのひずみ振幅につい て繰返しせん断の周期を $0.2,0.5,2.0,10.0$ 秒と変化 させた。

なお今回行った実験条件, 供試体の個数の一覧を Table 2 に示文.

繰返しせん断中は, せん断応力, せん断変位, 鉛直変 
Table 2 Testingconditions for cyclic simple shear test on saturated kaolinite clay.

\begin{tabular}{|c|c|r|c|c|}
\hline $\begin{array}{r}\sigma_{\mathrm{vo}}^{\prime} \\
(\mathrm{kPa})\end{array}$ & OCR & $n$ & $\begin{array}{c}\mathrm{T} \\
(\mathrm{s})\end{array}$ & $\begin{array}{c}\text { Number } \\
\text { of Data }\end{array}$ \\
\hline 49 & 1 & 200 & 0.2 & 8 \\
49 & 1 & 50 & 0.5 & 1 \\
49 & 1 & 200 & 0.5 & 13 \\
49 & 6 & 50 & 0.5 & 1 \\
49 & 6 & 200 & 0.5 & 11 \\
49 & 1 & 50 & 2.0 & 1 \\
49 & 1 & 200 & 2.0 & 23 \\
49 & 6 & 50 & 2.0 & 1 \\
49 & 6 & 200 & 2.0 & 13 \\
49 & 1 & 50 & 10.0 & 1 \\
49 & 1 & 200 & 10.0 & 12 \\
49 & 6 & 50 & 10.0 & 1 \\
49 & 6 & 200 & 10.0 & 8 \\
\hline
\end{tabular}

位，供試体下面での過㮃間隙水圧の測定を行った。繰返 しせん断終了後は，非排水状態のまま過剩間隙水圧が一 定值になるまで放置し，その後供試体上面より排水を行 い, 圧密沈下量, 供試体下面の過剩間吵水圧の時間的変 化を測定した.

\section{5. 繰返しせん断の周期が過剩間隙水圧の上 昇過程に及ぼす影響}

Fig. 2(a)，（b)，（c）は正規圧密粘土について，周期 $T$ を $10.0,0.5,0.2$ 秒とし, Uずみ振幅を種及変化させ て得られた過剩間隙水圧の上昇過程を示したものであ る. また同様に Fig. 3(a)，(b)は OCR=6について周 期 $T=10.0 ， 0.5$ 秒として得た結果である. Uずみ振幅 との対応から明確ではないが，いずれの過圧密比につい ても, 繰返しせん断開始直後においては, 周期が短いほ ど累積する過剩間陌水圧は小さくなっている.また, $T=$ 0.2 秒（Fig. 2(c)) の場合においては， $n=200$ 回で繰 返しせん断を終了後もわずかに過剩間隙水圧の上昇がみ られる。このような繰返しせん断停止後に過剩間隙水圧 が上昇するという傾向は動的三軸試験によっても得られ ており9), 今回用いた供試体の厚さは $2 \mathrm{~cm}$ と動的三軸試 験の供試体に比べて非常に小さいにもかかわらず，三軸 試験と同様な傾向が得られた。

な抧，間隙水圧測定值のタイムラグによる誤差を Bishop ${ }^{10)}$ にってて示された方法に従って求めたところ, 最大でも約 $1 \%$ であること，また供試体は厚さが $2 \mathrm{~cm}$ と薄く, 供試体内の間隙水圧の不均一性に基づく誤差も 小さいことから，先述の現象は間隙水圧計測上の問題に 起因したものではないと思われる。

なお，図中の記号はいずれも実測值であり，実線は実 測值に対して式 (1)により双曲線近似したものである. また, 式 $(1)$ は, $n /\left(u_{d y n} / \sigma_{v o}^{\prime}\right)$ と $n$ の関係が線形関係にな ることを示しており,この直線の切片の值が $\alpha$, 勾配が $\beta$ であって, $n \rightarrow \infty の と き u_{d y n} / \sigma_{v o}^{\prime}$ は $1 / \beta$ となる。
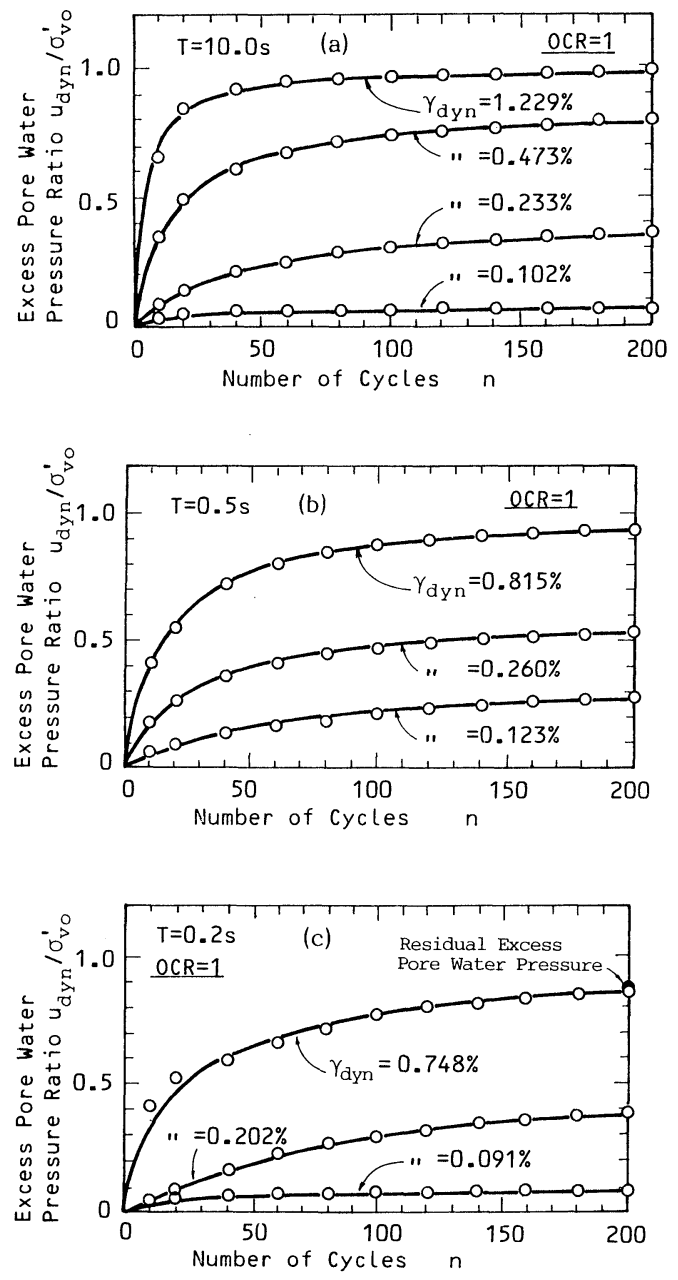

Fig. 2 Excess pore water pressure induced by cyclic shear $(\mathrm{OCR}=1)$.

そこで, 個々の実験について $\alpha, \beta$ を求めた後, 各 OCR に対する $\alpha \sim \gamma_{d y n}$ 関係および $\gamma_{d y n} / \beta \sim \gamma_{d y n}$ 関係のグラフ をFig. 4(a)，（b)，Fig. 5(a)，（b)のよjに描くと， それぞれの直線の勾配と切片から, 式 (2)，（3)中の係 数 $A, m, B, C$ が求まる.

一方, 式(4)の $D, E$ は $\mathrm{OCR}=6$ の結果において, 各 周期についての $\Psi \sim \log \gamma_{d y n}$ の関係から求まる.

これらの係数をもとに，式(1)によって $u_{d y n} / \sigma_{v o}^{\prime} \sim n$ の関係を示したものがFig. 6, 7 であって，それぞれ $\mathrm{OCR}=1 ， 6$ の結果である. 図中にはひずみ振幅を $0.1 \%$ $\sim 1.5 \%$ の間で変化させ, 周期を 0.2 秒, 0.5 秒, 2.0 秒, 10.0 秒として得た結果を示している.

Fig. 6, Fig. 7 には, Fig. 4(a), (b), Fig. 5(a), (b)で示したように， $\alpha, \beta$ についてのデータのばらつき 

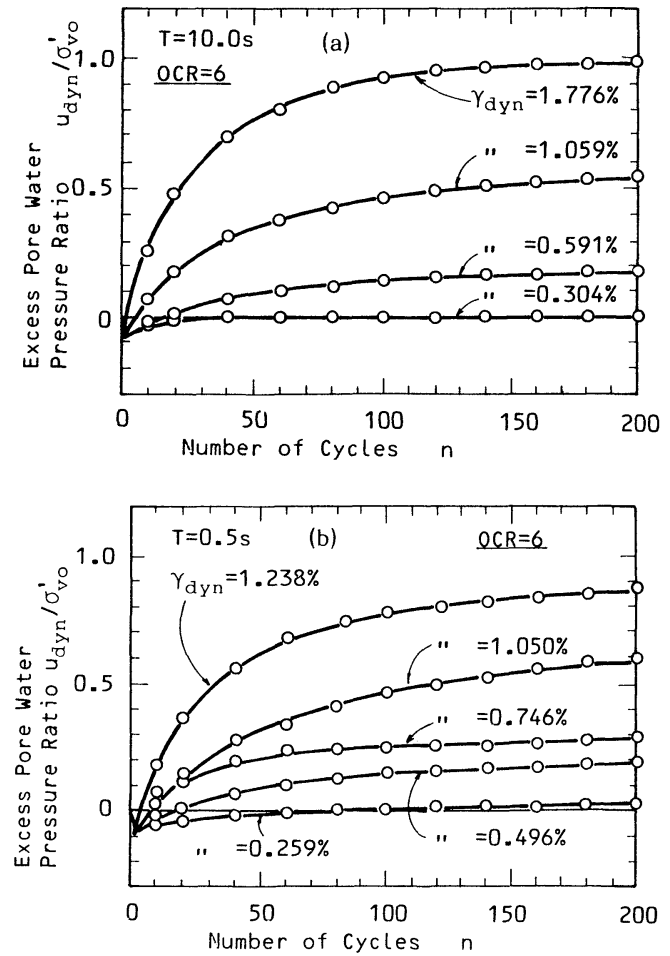

Fig. 3 Excess pore water pressure induced by cyclic shear $(\mathrm{OCR}=6)$.

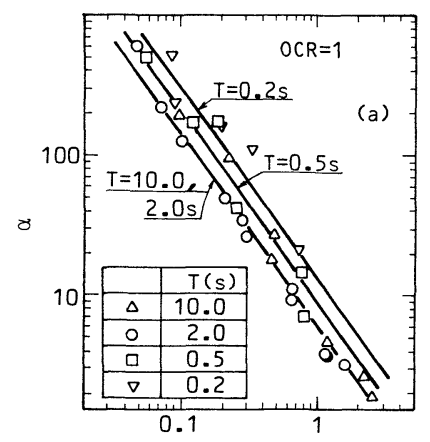

Shear Strain Amplitude $\gamma_{d y n}(\%)$

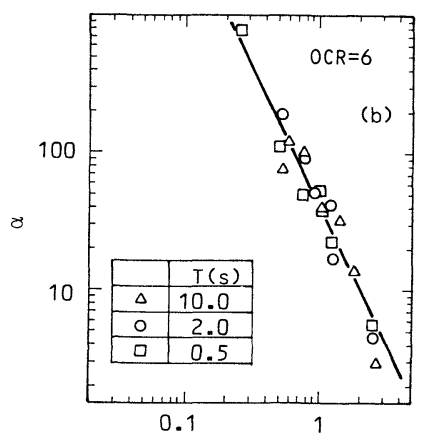

Shear Strain Amplitude $\gamma_{\text {dyn }}(\%)$

Fig. $4 \alpha$ versus cyclic shear strain amplitude.
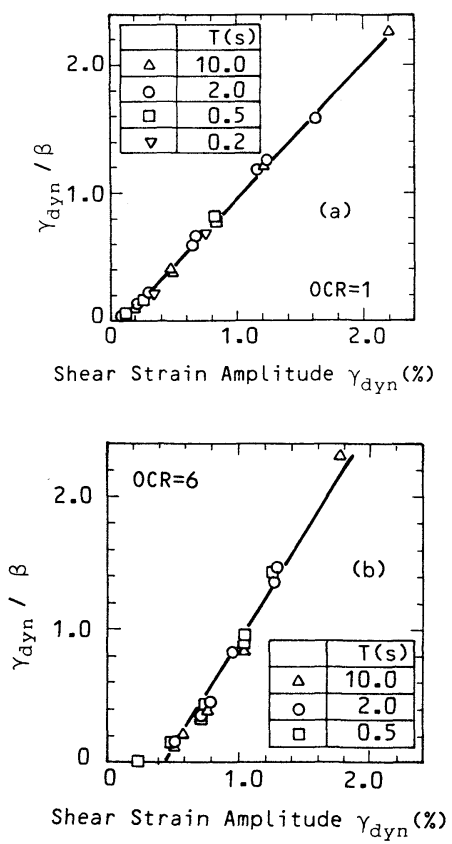

Fig. $5 \beta$ versus cyclic shear strain amplitude.

が含まれているが, Fig. 6 より OCR $=1$ の場合, $\gamma_{d y n}=$ $0.1 \%$ ときは周期の影響はみられない.しかし，ひずみ 振幅が大きくなると, 周期 $T$ が長いほど過剩間隙水圧の 初期の立ち上がりの勾配が急になり, $n=200$ 回での過剩 間隙水圧の值にも相違がみられる.すずに, 赤木 ${ }^{10)}$ 動的 三軸試験によって周期を 0.1 秒と 1.0 秒とした実験を行 い同様の結果を得ている.これに対して, OCR =6の場合 にはFig. 7 からわかるように，周期の影響はみられな w.

Fig. 8，9 は，それぞれ OCR=1，6の供試体について Uずみ振幅をそれぞれ約 $2.2 \%, 1.8 \%$ とし， $n=50$ 回の 繰返しせん断後, 非排水状態を保った場合の過剩間隙水 圧の変化を示したものである.Fig. 8 において, $n=50$ 回 までの過剩間隙水圧の上昇過程をみると, 周期が短い方 が過㮃間隙水圧の上昇は遅くなっており, Fig. 6 と同様 である.これに対して, Fig. 9 では, $n=50$ 回までの過 㮃間隙水圧の上昇過程に及ぼす周期の影響はみられな W.

実験では, $n=50$ 回の繰返しせん断を与えた後非排水 状態を保って, 過剩間吵水圧の変化を調べたが, Fig. 8 に おいて周期が 10,2 秒の場合には, 過剰間隙水圧の值に変 化はみられない.しかし, 周期 0.5 秒の場合は, 過剰間 隙水圧は繰返しせん断停止後さらに上昇し約 1.0 分後に 周期 $T$ が 10,2 秒の曲線に一致している.同様なことは, $n=200$ 回とした場合にも確認されている. 先述したよう 


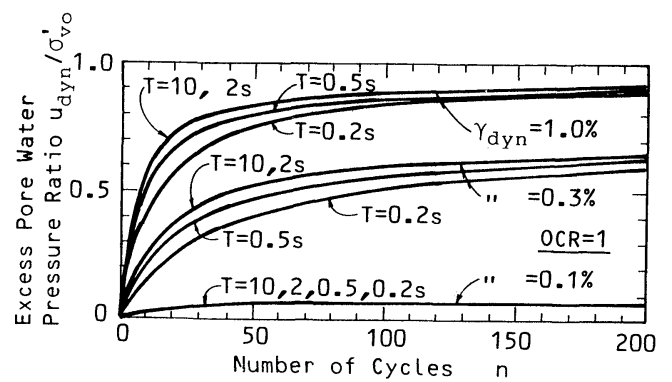

Fig. 6 Excess pore water pressure calculated by Eq.(1) $(\mathrm{OCR}=1)$.

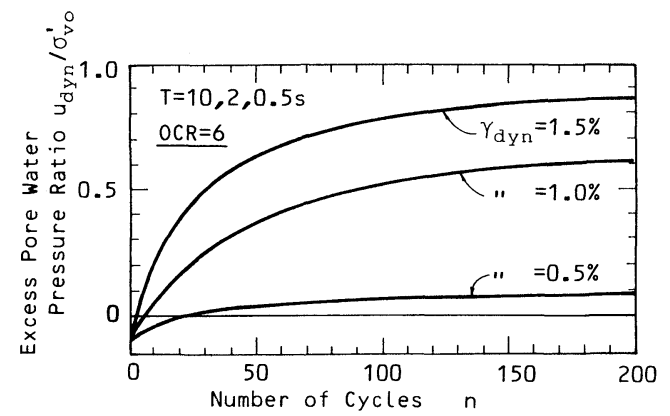

Fig. 7 Excess pore water pressure calculated by Eq.(1) $(\mathrm{OCR}=6)$.

に，このような繰返しせん断停止後の過剩間隙水圧上昇 は，Matsui ${ }^{9}$ による繰返し三軸試験結果においても確認 されている。すなわち，単純せん断試験のように薄い供 試体であっても繰返しせん断停止後に過㮃間隙水圧の変 化を生じるということである，ただ，繰返しせん断停止 後非排水状態のまま放置すると, いずれの周期において も過剩間隙水圧は一定值に収束する。

これに対して, OCR $=6$ の場合には, 繰返しせん断中お よび繰返しせん断停止後いずれのひずみ振幅においても 過剩間隙水圧に及ぼす周期の影響はほとんどみられな い.

また, Fig. 9 においては, 繰返しせん断停止後間隙水 圧の減少傾向がみられ, Fig. 8 とは顕著な相違を示して いる.これはFig. 9 では過圧密化が 6 と大きいため, 供 試体は本来時間遅れを伴って膨張する傾向をもってお ク，それが繰返しせん断停止後も引き続いて現われるた めに生じたと考えられる。

以上のように, $\mathrm{OCR}=1$ と OCR $=6$ という過圧密比が 極端に離れた現象の対比ではあるが, OCR が大きくなる と過剩間隙水圧の上昇過程に及ぼす周期の影響はなくな ク，また繰返しせん断停止後の過㮃間隙水圧の挙動も異 なる。つまり，OCR が異なると繰返しせん断によって累 積する過剩間隙水圧も著しく影響されるということであ

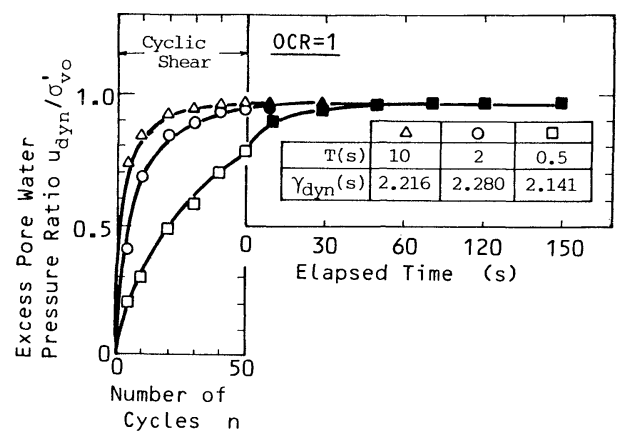

Fig. 8 Relationships between $u_{d y n} / \sigma_{v o}^{\prime}$ and elapsed time $(\mathrm{OCR}=1)$.

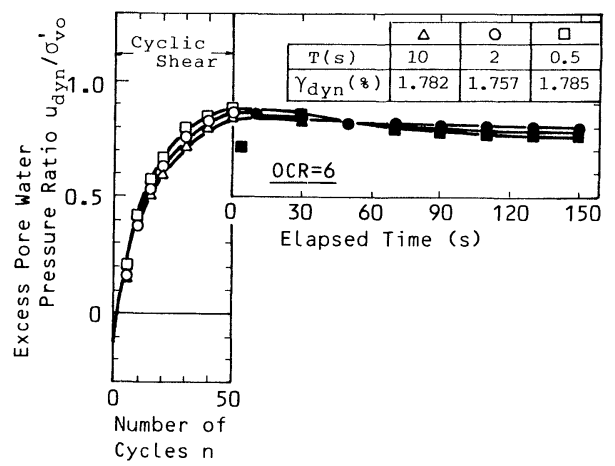

Fig. 9 Relationships between $u_{d y n} / \sigma_{v o}^{\prime}$ and elapsed time $(\mathrm{OCR}=6)$.

る.

次に, 式 (1)より, 次式が得られる.

$\Delta u_{d y n} / \sigma_{v o}^{\prime}=\partial\left(u_{d y n} / \sigma_{v o}^{\prime}\right) / \partial n=\alpha /(\alpha+\beta \cdot n)^{2}$

式 ( 7 ) 中の $\Delta u_{d y n} / \sigma_{v o}^{\prime}$ は, 1 サイクルの繰返しせん断に よって累積する過剰間隙水圧増分を示しており, この值 は繰返し回数の増加に伴うひずみ履歴効果をみるうえで 重要である，そこで，先述の係数を用いて， $\Delta u_{d y n} / \sigma_{v o}^{\prime} \sim$ $n$ の関係を求めた結果が Fig. $10(\mathrm{a}),(\mathrm{b})$, および Fig. 11 で, Fig. 10(a), (b)は, OCR=1について, ひずみ 振幅 $\gamma_{d y n}$ をそれぞれ $0.3,1.0 \%$ そして Fig. 11 は $\mathrm{OCR}=6$ で $\gamma_{d y n}$ を $0.5,1.0,1.5 \%$ として得たものであ る.

Fig. 10(a)においては, ひずみ振幅が小さい（ $\gamma_{d y n}=$ $0.3 \%)$ 場合は $n \leqq 30$ のとき, 周期 $T$ が長い方が $\Delta u_{d y n} /$ $\sigma_{v o}^{\prime}$ は大きく, $n$ がそれ以上になると逆に周期の短い方 が大きくなっている．同様の傾向はひずみ振幅が $1.0 \%$ (Fig. 10 (b )) の場合にもみられ，この場合には， $n \geqq 15$ において周期の短い方が $\Delta u_{d y n} / \sigma_{v o}^{\prime}$ は大きくなってい る.

一方 $\mathrm{OCR}=6$ の場合は, Fig. 11 より $\Delta u_{d y n} / \sigma_{v o}^{\prime} \sim n$ の 

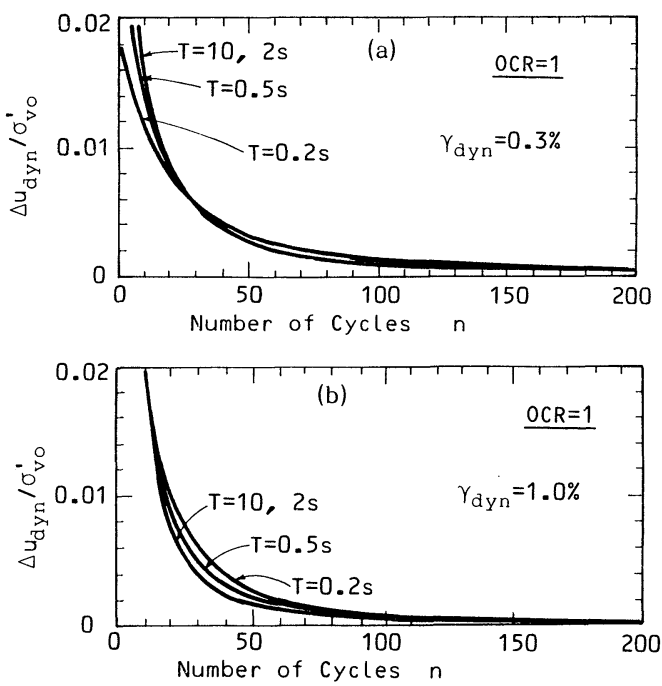

Fig. 10 Relationships between $\Delta u_{d y n} / \sigma_{v o}^{\prime}$ and $n(\mathrm{OCR}=1)$.

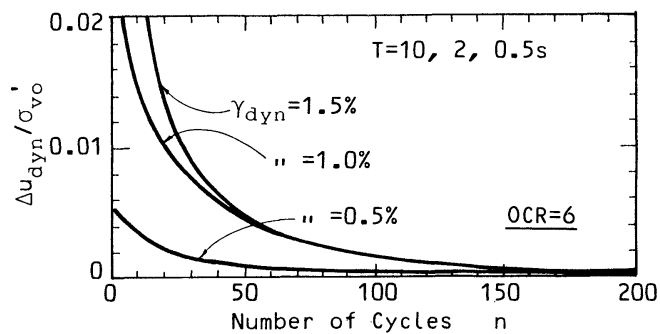

Fig. 11 Relationships between $\Delta u_{d y n} / \sigma_{v o}^{\prime}$ and $n(\mathrm{OCR}=6)$.

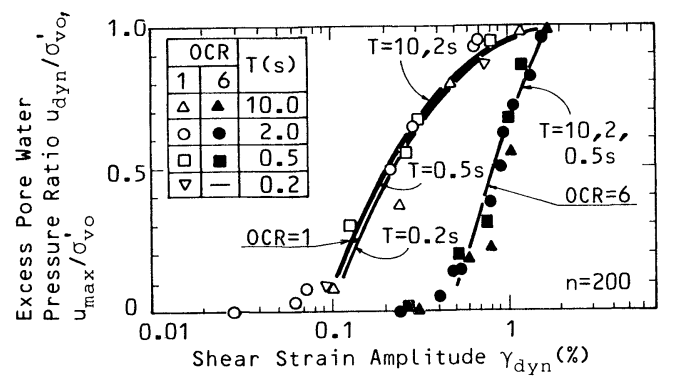

Fig. 12 Relationships between $u_{d y n} / \sigma_{v o}^{\prime}, \mathrm{U}_{\max } / \sigma_{v o}^{\prime}$ and $\gamma_{d y n}$.

関係に及ぼす周期の影響はみられない.

Fig. 12 は, $n=200$ 回の繰返しせん断後過㮃間隙水圧 が十分安定した後の間隙水圧比を $u_{\max } / \sigma_{v o}^{\prime}$ として，ひず み振幅との関係で示したものである。図中の記号は実測 值であり，実線は式 $(1)$ によって得たものである，同図 では OCR=1の場合, ずかではあるが計算值は周期 $T$ が長いほど大きくなることを示している。これは実測值 が, $n=200$ 回の繰返しせん断後過剩間隙水圧が十分安定
してからの值であるのに対して，計算值は $n=200$ 回の 繰返しせん断直後の值であることに起因している。

\section{6 ．過剰間吵水圧の消散に伴う沈下について}

繰返しせん断によって累積した過剰間隙水圧は，排水 によって消散し，そのとき沈下を生じる。

Fig. 13 は, 繰返しせん断によって累積した過㮃間隙水 圧の消散に伴う間隙比の変化量 $\Delta e$ と $\log \left\{1 /\left(1-u_{d y n}\right\}\right.$ $\left.\sigma_{v o}^{\prime}\right\}$ の関係で，それぞれ $\mathrm{OCR}=1 ， 6$ の結果である.ここ に, $\log \left\{1 /\left(1-u_{d y n} / \sigma_{v o}^{\prime}\right\}\right.$ は, 対数スケール上での過剩間隙 水圧の変化量, つまり有効応力の減少量を示している.

Fig. 13 より，多少ばらつきはあるものの，各周期につ いて得られた結果はほぼ一直線上にある。また，この直 線の勾配は, $e \sim \log p$ 関係における直線の勾配に対応す ることから，「繰返しせん断を受けた粘土の圧縮指数」 $C_{d y n}$ とよんでいる ${ }^{4)}$. 同図には, 種々のUずみ振幅の結果 も含まれているが, すでに示されている4)ように, $C_{d y n}$ は ひずみ振幅によって影響されないだけではなく，繰返し せん断の周期によっても影響されないことがわかる。こ のことは, 繰返しせん断後の排水過程で生じる沈下は繰 返しせん断中に生じる過㮃間隙水圧の大きさのみによっ て決定されることを示している.

繰返しせん断を受けた粘土の圧縮指数 $C_{d y n}$ を用いる ことにより，繰返しせん断後の排水によって生じる間隙 比の変化 $\Delta e$ および沈下ひずみ $\varepsilon_{v}$ は, 式 $(5),(6)$ に よって得られる。

Fig. 14 は, 繰返しせん断中に累積した過剩間隙水圧の 消散によって生じる沈下ひずみとひずみ振幅の関係を示 したものである，図中の記号は実測值であり，曲線は式 (6)より得られた計算值である. 同図より，記号で示し た実測の沈下ひずみはいずれの OCRに対しても，周期 $T$ によらずほぼ一定になっている．しかし， OCR=1の 場合に扔いては, 計算値において周期 $T$ が短いほど沈下 ひずみは小さくなる傾向が現われている。これは先述し

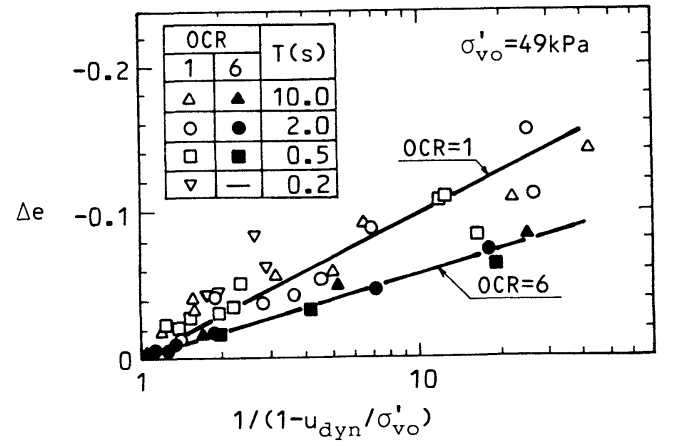

Fig. 13 Change of the void ratio due to the dissipation of excess pore water pressure. 


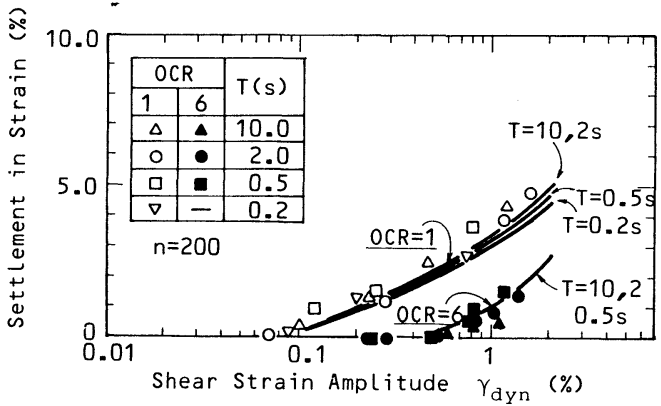

Fig. 14 Settlement induced by cyclic shear.

たように, 周期 $T$ が短いときは繰返しせん断が終了した 後も過㮃間隙水圧は上昇するが, 計算值では繰返しせん 断中の過剩間吵水圧の上昇に対してカーブフィッティン グしているためである.ただ，ひずみ振幅が $0.5 \%$ 程度以 下では計算值においても周期の影響はほとんどないこと がわかる。

すなわち，繰返しせん断中に累積した過剩間隙水圧を 消散させることによって生じる沈下ひずみに及ぼす周期 の影響はないということであり，このことは地震等に起 因した粘土層の沈下量を推定する場合，周期の影響は考 慮しなくてもよいということで, この結果は解析上有用 である。

\section{7.まと め}

本研究では, 動的単純せん断試験機を用いて, 過圧密 比の異なる飽和粘土が，種々の周期の繰返しせん断を受 けた場合に累積する過剩間隙水圧，およびその消散に伴 う沈下について調べた. その結果以下のことが明らかに なった.

（1）正規圧密粘土において，ひずみ振幅を一定とし た繰返しせん断では，周期が長いほど累積する過㮃間陌 水圧は大きい. しかし，過圧密比が大きい $(\mathrm{OCR}=6)$ と き過唾間隙水圧に及ぼす周期の影響はみられない.

（2）正規圧密粘土においては，繰返しせん断の周期 が短いとき，繰返しせん断停止後もわずかな過剩間隙水 圧の上昇がみられる.しかし, 非排水状態を継続すると, 周期に関係なく過剰間吵水圧の值は一定となる. 一方, 過圧密粘土 $(\mathrm{OCR}=6)$ では, 繰返しせん断停止後わずか に過唾間隙水圧が減少する傾向がみられ，正規圧密粘土 の場合と異なる。

（3）正規圧密粘土においては周期が短いとき，繰返 しせん断中に累積する過剩間隙水圧は周期の影響を受け
る.しかし，いずれの実験条件の場合でも，過㮃間隙水 圧值は繰返しせん断停止後短い期間内においてある值に 収束し，かつその大きさは周期の影響を受けない。その ため，繰返しせん断に起因して生じる間隙比の変化およ び沈下ひずみも周期の影響を受けない.

終わりに, 本研究にあたって山口大学の椋木 隆技官, および当時の同大学学生 佐野修司, 生垣聡志君の助力を 得た。ここに謝意を表します。

\section{参 考 文 献}

1) Zeevaert, L.: Foundation engineering for difficult. subsoil conditions, Van Nostrand Reinhold Company, pp.522 523, 1972.

2) Jaime Alberto P., Miguel P. Romo and Mario Jasso $\mathrm{R}$. : Seismic induced settlement in a building, 8th Panamerican Congress on Soil Mechanics and Foundation Engineering, pp.257 275, 1987.

3）鈴木猛康：動的応力履歴を受けた飽和粘性土の沈下挙 動，応用地質，Vol.25，No. 3, pp.21 31，1984.

4) Ōhara, S. and Matsuda, H. : Study on the settlement of saturated clay layer induced by cyclic shear, Soils and Foundations, Vol. 28, No. 3, pp.103 113, 1988.

5）梅原靖文・大根田秀明 - 樋口嘉章：粘性土の動的強度特 性に関する周期の影響, 第 17 回土質工学研究発表会, pp. 1713 1716, 1982.

6) Fischer, J.A., Koutsoftas, D.C. and Lu, T.D. : The behavior of marine soils under cyclic loading, Proceedings of the Conference on Behavior of Offshore Structures, Vol. 2, pp.407 417, 1976.

7) Procter, D.C. and Khaffaf, J.H. : Cyclic triaxial tests on remolded clays, Journal of Geotechnical Engineering, Vol. 110, No. 10, 1984.

8) Brown, S.F., Lashine, A.K.F. and Hyde, A.F.L. : Repeated load triaxial testing of a silty clay, Geotech nique, Vol. 25, No. 1, pp.95 114, 1975.

9) Matsui, T., Ōhara, H. and Ito, T.: Cyclic stress -strain history and shear characteristics of clay, Journal of the Geotechnical Engineering Division, ASCE, Vol. 106, No. GT10, pp.1101 1120, 1978.

10) Bishop, A.W. and Henkel, D.J. : The measurement of soil properties in the triaxial test, Edward Arnold Ltd., pp.192 204, 1964.

11）赤木寛一・大塚敬三：非排水繰返し載荷が飽和粘性土の 力学特性に及ぼす影響一特に繰返し載荷周波数と土の乱 れの大きさの関係について一, 第 21 回土質工学研究発表 会, pp.667 668, 1986.

(1989.8.3・受付) 